\title{
Employee Turnover in the Fast Food Restaurants: Investigating the Role of Human Resource Management Practices
}

\author{
Fayez Bassam Shriedeh \\ School of Hospitality and Tourism, Luminus Technical University College (LTUC), \\ Amman, Jordan, +962-79-7188993 \\ E-mail: F.Shriedeh@ltuc.com
}

Received: Oct. 3, 2019 Accepted: Oct. 25, 2019 Online published: Nov. 8, 2019

doi:10.5296/ijhrs.v9i4.15559 URL: https://doi.org/10.5296/ijhrs.v9i4.15559

\begin{abstract}
High Turnover (TO) rate among Fast Food Industry (FFI) employees is a critical issue faced by the Jordanian hospitality industry and be detrimental to the growth of the industry. Following that, is important to analyse the factors that lead to high TO rate among FFI employees. This study aims to examine the effect of Human Resource Management Practices (HRMP) and Intention to Leave (ITL) among FFI employees in Jordan. Five HRMP have been included in this study namely training, reward, benefit, performance appraisal and staffing. Using a sample of 245 FFI front-line employees working in Amman, this study has employed a quantitative research approach to answer the research questions. Multiple regression analyses using SPSS was performed to test the hypotheses of this study. As expected, HRMP namely, reward and benefit dimensions of HRMP found to be most significant practices in influencing ITL in this study. The findings of this study contribute to existing literature on the management of Human Resource (HR) and employee TO. It provides insights on the relationships between HRMP and ITL. Practical implications are also provided to managers to reduce TO among FFI employees in Jordan.
\end{abstract}

Keywords: human resource management practices, intention to leave, Jordan

\section{Introduction}

Generally, fast food can be described as foods that are prepared and served in shortest time. Hence, they deliver same menu and standardized quality to minimize the period for the buyer to get product detail (Jekanowski, Binkley \& Eales, 2001). Fast food is categorized to be a frequent choice, convenient for customers, delicious, and have a sensible price. Globally, it's 
the fastest emerging food category in the world (Xiao, Yang, \& Iqbal, 2018), generated almost USD 495.0 billion in 2014 (Food \& Beverage Magazine, 2019) and more than USD 539.63 Billion in 2016 (Zion Market Research, 2019). The FFI is expected to earn a value of USD 690.80 Billion in 2022 (Zion Market Research, 2019) and USD 843.4 Billion by 2026 (Straits Research, 2019). Middle East and Africa is expected to record rapid development during the outlook period, 2019-2026, owing to expansion of business and tourism activities by key players in the region (Straits Research, 2019).

In Jordan, the FFI has been the most favored selection for majority of the customers due to the instant meal preparation which enables them to eat within a short time. The FFI is made of a various range of food outlets that offer numerous distinctive dishes ranging from local to international. However, traditional fast food meals include shawrma, burger, falafel, fried chicken and sugar-sweetened beverages. Meanwhile, International fast food meals include pizza, burgers, beef, macaroni, chicken nuggets, pizza, sugar-sweetened beverages, and etc. The major fast food franchising operators are McDonald's, Kentucky Fried Chicken (KFC), Pizza Hut, Burger King, Domino's Pizza, Hardee's, and Subway. This sector is well recognized as one of the most significant segments of the Jordanian economy and significantly contributes to employment (Jordanlens, 2016). It is estimated that Jordanians spend over USD 1.6 billion a year at FFI (Obeidat, 2014).

High employee TO among FFI workers is a global concern (Davis, 2018; Ferreira, Martinez, Lamelas, \& Rodrigues, 2017; Pei \& Chee, 2019; Xiao et al., 2018) including Jordan (Ikhlas \& Al-kilani, 2010; Khawaldeh, Muala, \& Ziadat, 2014). Kumar, Ramendran, and Yacob (2012) stated that $70 \%$ of fast food employees planned to leave the restaurant industry in two years of the first working day. Employee TO in the FFI has negative consequences on restaurants performance. These adverse effects including poor service quality (Al Momani, 2017), increased operation cost and cost of re-staffing (Deery, 2008), increased training costs (Tews, Michel, \& Ellingson, 2013), tarnished image and declining productivity (Blomme, Van Rheede, \& Tromp, 2010), loss of both revenue (Holston Okae, 2018) and competitive advantage (Davis, 2018). A low TO rate will enable business pioneers to reduce operational costs, boost strategic manpower planning, and enhance their competitiveness (Derindag \& Canakci, 2019).

It has been argued that employee TO is a major challenge for organizations yet companies that have implemented effective HRMP can promotes employee satisfaction (Alfes, Shantz, Truss, \& Soane, 2013; Türkmen \& Taşpınar, 2019) and reduce the rate of ITL (Hashim, Ghazali, Mohamad, Rasdi, \& Othman, 2019; Holston Okae, 2018; Türkmen \& Taşpınar, 2019). This also emphasized by Phillips (1996) by stating, "HR programmes designed to reduce turnover can result in tremendous bottom line improvement" (p. 180). It is therefore important to implement practices which would make employees satisfied with their job at all times and therefore influence their intention to stay with the organization. Complex environment has been widely discussed in the Human Resource Management (HRM) literature that companies retain and manage their employees by setting up a wide range of HRMP (Alfes et al., 2013; Ikhlas \& Al-kilani, 2010).

These practices regulars include designing fair job and recruitment, providing inclusive 
training and development opportunities, and improving compensation and incentive pay scales and so on (Alfes et al., 2013) which may differ from one another with respect to organizations and countries as several researchers have attempted to identify the various HRMP employed in different sectors (Ikechukwu, 2017). Consequently, after reviewing the relevant literature on HRMP, the focus of this study includes HRMP of training, performance appraisal, staffing, rewards and benefits.

In the same way as other managerial themes, there is a scarcity in empirical research relating to TO (Self \& Gordon, 2019) and HRMP in developing countries regardless of calls to expand the international HR perspective (Ikechukwu, 2017; Ikhlas \& Al-kilani, 2010). This gap of knowledge limits settings pertaining to HRM theory (Ikhlas \& Al-kilani, 2010). Subsequently, HR professionals in developing countries face an absence of focused strategies for combating high TO rates and promoting FFI performance (Allen, 2017). Therefore, the present research paper aims to investigate the effect of HRMP on ITL phenomenon in the Jordanian FFI.

The uniqueness of this research is to study the effects of each HRMP as multidimensional construct on ITL in the Jordanian context, where there is an urgent need for more research work to be conducted (Ikechukwu, 2017; Ikhlas \& Al-kilani, 2010).

\section{Literature Review}

\subsection{Intention to Leave}

ITL has been an important issue in FFI. High ITL proportion in the organizations causes high cost of recruitment and decline of organizational performance (Almalki, FitzGerald, \& Clark, 2012). In this way, ITL is an undesirable occurrence in the organizations, on the grounds that long haul efficiency is influenced by procuring the best qualified work force, as well as keeping them in the organization for out stretches of time.

ITL refers to thee "conscious and deliberate" will of an employee to leave an organization within a certain time frame (Halawi, 2014). Scholars in the field of HRM defined it as "the rotation of employees around the market; between the firms, jobs, and occupations; and between the states of employment and unemployment" (Tuji, 2013). With the advancement of technology and accelerating of globalization, people change their jobs as many times they wish on their own decision not as a result of company closure (Ikechukwu, 2017). Consistent with this view, Chen and Tung (2014) argued that ITL can safely be used as a substitute for TO behavior. Further, past studies had clarified that ITL is probably one of the greatest predictors and an immediate indication of employee's TO (Iqbal, Ehsan, Rizwan, \& Noreen, 2014; Sun, Wei \& Lu, 2010). Other researchers like Haider, Ahmed, and Ali Asadullah (2019) and Saraih, Aris, Sakdan and Ahmad (2017) have viewed ITL as the best predictor of actual TO.

There is a motivation to distinguish between whether the TO is initiated by the employer or employee. Involuntary TO is initiated by the employer and regularly incorporates low employee performance and consequently the organizational performance may be better after the dismissal (Sawaneh \& Kamara, 2019). High proportion of involuntary TO indicates that the organizations had a problem with workforce quality (Maltarich, Reilly, \& DeRose, 2019; 
Sawaneh \& Kamara, 2019).

Voluntary TO that is initiated by an employee, demonstrates a misfortune of human capital that the organization would surpass to avoid, since the workers that the organization most frequently would have liked to retain or at least not expel (Maltarich et al., 2019). Within the field of research that has been proceeded on TO, it has been deemed more imperative to search at why individuals decide to leave the organizations voluntarily (Hur \& Achen, 2013). Eventually the objective is not to revoke TO completely, since a certain stream of workers is critical for an organization. There will always be some involuntary TO from the layoffs the organization chooses to make, e.g. to get rid of poor performing workers (Jeswani \& Jaiswal, 2014).

In the literature, employee TO remains a vibrant field of further research even though more than 1500 studies have been conducted already (Holtom, Mitchell, Lee, \& Eberly, 2008). Majority of the studies assessed the ITL rather than the actual leaving because many evidence showed that intention is the immediate predictor to the actual behavior (Jha, 2009). Prior research (Omar \& Noordin, 2013, 2015, 2016; Saraih et al., 2017; Yamona, 2014) propose that TO intentions are not only the foremost indicators of actual TO, but also represent the final step in the TO process prior to actually quitting. Similarly, in this ITL will be studied as the proxy of actual TO. Despite all these efforts, there is still no universal agreement on the factors that explain neither the actual TO or ITL.

The employee ITL phenomenon is regarded as complex, thus causes of ITL differ in the context of research, and nature of the organizations (Saraih et al., 2017). While considerable number of individual factors has been studied thus far, organizational factors known to influence ITL have only been marginally assessed (Ikechukwu, 2017; Omar \& Noordin, 2013). Most of the previous research in this area has been done either in the manufacturing or production industry (Alfes et al., 2013; Ikhlas \& Al-kilani, 2010). Studies in the manufacturing industry cannot be generalized to the service settings such as FFI because of the variations in innovation and technologies, work processes, interdependency among staff and the role of customers (Ikechukwu, 2017; Jha, 2009). As the TO rate in service sector is one of the highest of all industries, this area needs extra attention.

\subsection{Human Resource Management Practices}

Human Resources (HR) is considered as people that work in the organization responsible for implementing, creating, and supervision of policies that govern employee behavior and that of organization behavior toward its employees and they are strictly connected with job satisfaction (Soane, 2013). The opportunity and motivation of an employee are absolutely connected to commitment and negatively connected to ITL (Ikechukwu, 2017). Haider et al. (2019) and Sawaneh and Kamara (2019) suggest that HRMP are formulated to improve the level of an organizations' performance.

Meanwhile, HRM refers to "organizational practices directed at managing the pool of HR and ensuring that the resources are employed towards the fulfilment of organizational goals" (Ikechukwu, 2017, p. 33), accountable for how people are treated, helping workers perform their various duties in organizations, compensating them for their labors (Aladwan, Bhanugopan, \& 
D’Netto, 2015) and solving problems that arise. Jansen and Roodt (2014) outlined HRM as the process of enlistment and selecting employee, giving introduction and acceptance, preparing and improvement, evaluation of employee (execution of appraisal), liberal compensation and benefits, propelling, keeping up legitimate relations with employees and with exchange unions, keeping up employee's safety, welfare and sound measures in consistence with work. Thus, HRM definitions are varies from one researcher to another and it can also change in accordance with the researchers' or practitioners' points of view (Ikechukwu, 2017).

Reid (2007) has stated that HRM has five key functionalities:

(1) Staffing is the process of filling a vacant position of the right workforce at the right position and the right time, considering employees' capabilities, talent, and specializations that make them engaged in their jobs and also promote co-operative and healthy workplace environment (Choi, Boyle \& Dunton, 2014). Staffing process includes both recruitment and selection (Aladwan et al., 2015).

(2) Performance Appraisals is "a systematic and formal process by means of which the job relevant strengths and weaknesses of employees are identified, observed, measured, recorded and developed" (Ikechukwu, 2017, p.44). Performance appraisal forms could be in technical, behavior, physical, or physiological aspects (Aladwan et al., 2015).

(3) Training is also identified as an important element to lessen deliberate TO (Memon, Salleh, Harun, Rashid, \& Bakar, 2014; Stewart \& Brown, 2019). Training is characterized as the methodologies applied to instruct staff to carry out work strategies in the most ideal way. Contemplates have demonstrated that training can enhance the employees' capacity of adapting new abilities, learning, disposition and practices in a workplace. Training can have a positive impact with respect to decreasing ITL.

(4) Rewards are a capable tool utilized for employment engagement. Perceiving and rewarding the employees successfully is urgent for holding top ability and keeping employees glad. Prouska et al. (2016) emphasized that reward system includes all forms of financial and non-financial, direct and indirect, intrinsic and extrinsic an employee gets as part of an employment relationship. Every employee is willing to have some level of rewards after accomplishing a certain task (Holbrook \& Chappell, 2019).

(5) Benefits are also considered as another form of reward in a vital reward system, and the employees are interested to know the sorts of benefits the organizations give. Organizations that don't coordinate or surpass the advantage levels of their competitors will experience issues pulling in and holding top specialists (Ikechukwu, 2017).

\subsection{Human Resources Management Practices and Intention to Leave}

Researchers revealed that HRMP play a critical role in organization's survival and profitability in addition to enhance work related- performance and achieving organizational goal successfully.

HRMP have been proposed as controlling factor in ITL between employees (Ikechukwu, 2017). Studies have found that the workers observations about the organization HRMP will straight 
forwardly impact their ITL. This recommendation is in accordance with the past consequences of TO examination of Allen, Hancock, and Vardaman (2014) who opined that negative view of HRMP will prompt increment in number of ITL. They suggested that HRMP will adversely impact workers' TO choice (Mvula, 2018; Wayne, Shore, \& Liden, 1997) HRM rehearses have been proposed as controlling element in ITL among employees (Ikechukwu, 2017; Meyer \& Smith, 2000). Thus, the following hypothesis is proposed:

H1: There is a negative effect between HRMP and intention to leave.

H1a: There is a negative effect between staffing and intention to leave.

H1b: There is a negative effect between performance appraisals and intention to leave.

H1c: There is a negative effect between training and intention to leave.

H1d: There is a negative effect between rewards and intention to leave.

H1e: There is a negative effect between benefits and intention to leave.

\section{Research Methodology}

This study is aimed to investigate the relationship between the dimensions of HRMP and ITL in FFI in Jordan. The objective population in the review is focused on employees working in popular fast food restaurants brands such as KFC, McDonald's, Pizza Hut, Subway, Domino's, and Burger King. These brands were chosen because they are among the biggest chains with a significant number of employees. The research was conducted in Amman since majority of the fast food brands are located in this area. A convenience sample of 375 front-line employees was used. The data collection results in a return of 245 usable questionnaires for analysis out of the 375 questionnaires being distributed which resulted in $65.3 \%$ response rate.

ITL was measured with eight measurement items adapted from Wayne et al. (1997). HRMP was measured with 27 items adapted from Edgar and Geare (2005), Ikechukwu (2017), and Kinicki, Carson, and Bohlander (1992). All items utilizing a five point Likert ranging from $1=$ strongly disagree to 5=strongly agree. SPSS 21 was used for data analysis.

\section{Data Analysis and Results}

The results of demographic profile showed that the majority of respondents were male (55.4\%), with $65.3 \%$ of the participants were belonging to the age group below 30 years. Of these responders, $57.9 \%$ of them had a diploma degree. In addition, the majority $(75.5 \%)$ of respondents were single. In terms of respondents' monthly income, around $77 \%$ reported that their income below 300 JOD. In addition, the statistics shows that the majority of the respondents have working experience between 1 to 3 years accounted for $62.4 \%$ or 153 respondents of the sample.

The reliability analysis was conducted to ensure that the questionnaire in this study is reliable, consistent and stable, using Cronbach Alpha. The value of reliability coefficients for the all the questionnaires is above 0.7 (Awang, 2012). The overall HRMP shows reliability value of 0.833. The Cronbach Alpha for dimensions of HRMP is as follows: training shows 0.745 , 
performance appraisals was 0.709 , benefits was 0.780 , staffing 0.701 and reward show 0.723 . The Cronbach Alpha for ITL was 0.727. Thus, the construct and convergent validity were also supported (Hair, Black, Babin, \& Anderson, 2010).

Validity test was conducted using Principal Components Analysis (PCA). Only 27 measurement items of HRMP were subjected to analysis based on sample of 245 respondents. If factor loading of 0.6 and above for each item within its group then construct validity is assumed (Awang, 2012). While, Kaiser-Meyer-Olkin (KMO) rated 0.813, exceeding the recommended value of 0.6 (Awang, 2012, 2015) and Bartlett's Test of Sphericity (Awang, 2012) reached statistical significance $\mathrm{p}=0.000$, supporting the factorability of the correlation matrix. Varimax rotation was also conducted.

Table (1.1) shows a number of strong loadings, exceeding the recommended value of 0.6 , therefore the construct validity was supported and all variables loading substantially on only one component. The five-component solution explained a total of $70.976 \%$ of the total variance.

Table 1. Factors Loading of HRMP Scale

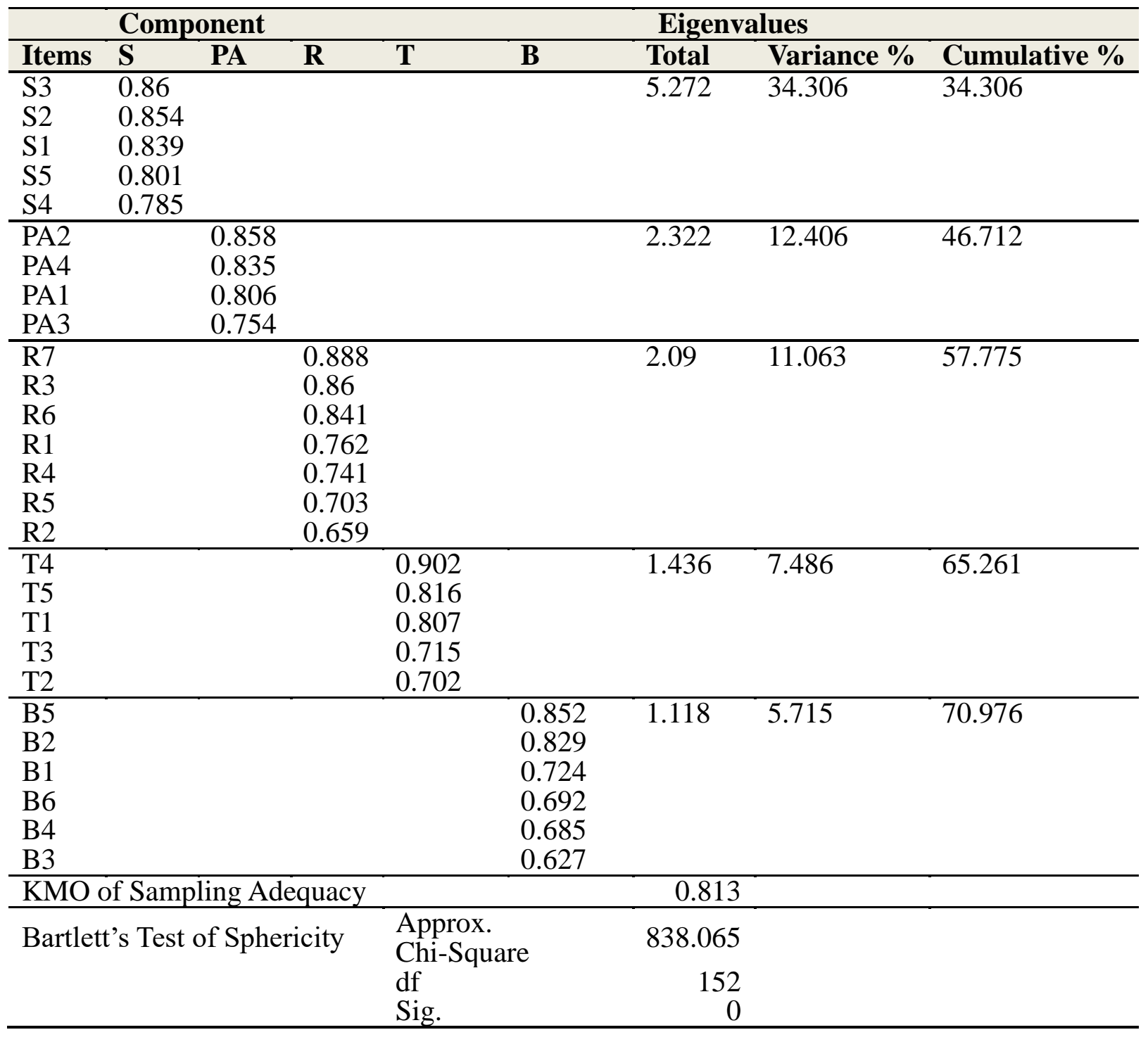




\section{Mll Macrothink}

International Journal of Human Resource Studies

ISSN 2162-3058

2019, Vol. 9, No. 4

Two regression analyses were performed to test hypothesis 1 as shown in Table 1.2. The first model performed to examine the effect of overall HRMP on ITL. The model was found statistically significant, $\mathrm{R}^{2}=0.088, \mathrm{~F}(1,295)=24.538, \mathrm{p}<0.05$. Overall HRMP was found negatively related to ITL $(\beta=-0.276, \mathrm{p}<0.05)$. This indicates that HRMP will lead to lower ITL among fast food employees. The result also suggests $8.8 \%$ of the variance in ITL is explained by HRMP which indicates it is important organizational support to avoid ITL. Therefore, the results suggest support for $\mathrm{H} 1$.

Meanwhile second model analyzed to examine the influence of HRMP dimensions on ITL. The model was found statistically significant, $R^{2}=0.102, F(5,290)=6.332, p<0.05$. Only reward $(\beta=-0.173, p<0.05)$ and benefit $(\beta=-0.168, p<0.05)$ dimensions of HRMP were found negatively related to ITL. This indicates that reward and benefit dimensions of HRMP is two main dimensions that lead to lower ITL. The result also suggests $10.2 \%$ of variance in ITL is explained by five dimensions of HRMP. Therefore, it is evident that only H1d and H1e were supported.

Table 2. Regression Analysis Results between HRMP and Intention to Leave

\begin{tabular}{lllll}
\hline Variable & & $\beta$ & $\mathrm{t}$ & $\mathrm{p}$ \\
\hline $\mathrm{HRMP}$ & & -0.28 & -4.86 & 0 \\
$\mathrm{R}^{2}$ & 0.088 & & & \\
$\mathrm{~F}$ & $(1,295)=24.538$ & & & \\
$\mathrm{P}$ & 0 & & & \\
\hline HRMP Dimensions & & & & \\
\hline Staffing & & -0.09 & -1.26 & 0.21 \\
Performance & & -0.04 & -0.52 & 0.61 \\
Training & & 0.072 & 0.905 & 0.37 \\
Reward & & -0.17 & -2.35 & 0.02 \\
Benefit & -0.17 & -2.13 & 0.04 \\
$\mathrm{R}^{2}$ & 0.102 & & & \\
$\mathrm{~F}$ & $(5,290)=6.332$ & & & \\
$\mathrm{P}$ & 0 & & & \\
\hline
\end{tabular}

\section{Discussion and Conclusion}

The objective of this study is to examine the effect of HRMP on ITL. The negative effect found between HRMP and ITL suggests that unsound HRMP definitely lead to an increase in TO. Sound HRMP are translating into a remote possibility of leaving an organization. Most research on the relationship between HRMP and work outcomes such as ITL has been conducted mainly in Western context.

Literature has reported that HRMP has a significant negative effect on ITL (Abeysekera, 2007; Abubakar, Chauhan, \& Kura, 2014; Bowling \& Hammond 2008; Cesário \& Magalhães, 2017; Chang, Chou \& Cheng, 2007; Long \& Perumal, 2014; Karavardar, 2013; Wayne et al., 1997; Zimmerman \& Darnold, 2009). Consistent with previous research findings, reward and benefit was found to be important HRMP that lead to greater ITL (e.g. Abeysekera, 2007; 


\section{MInstitute Macrothink $_{\text {Ins }}$}

International Journal of Human Resource Studies

ISSN 2162-3058

2019, Vol. 9, No. 4

Yumusak \& Yildiz, 2011). According to Derycke et al. (2010) and Feuerhahn, Kühnel, and Kudielka (2012), the imbalance of effort-reward which mean different between high efforts and low reward increase the ITL.

High effort and low reward in employee's professional life create ITL an organization (Jaffari, Aziz, Hussain, \& Akhtar, 2011; Long \& Perumal, 2014; Mburu, 2018). Other than that, the disappointment to be remunerated as expected may lead to discouragement and make them unmotivated and eventually will quite the job (Baru, Ali, Amin, \& Hamid, 2016; Mburu, 2018). Individual will continue to participate in organization as long as the rewards offered by the organizations are at least equal to or greater than the contributions required by the organization (Ikechukwu, 2017; March \& Simon, 1958). Based on the finding support that, we can conclude that an inadequately benefit and provide to employees affect employees decision to stay with organization, they have intention to join other organization which provide more attractive or adequate reward to them.

From the result of the research, HRMP have significant negative effect on ITL. This means that, when organizations have supportive HRMP for employees' especially attractive reward and benefit practices, lower ITL can be expected. The findings from this study are very crucial for the management of the FFI to understand the fast food employees' ITL. This research provided an opportunity for FFI to manipulate the HRMP and can reduce TO intention. This can help restaurants to increase their reputation and will increase loyalty among the staff.

\section{Limitations and Future Research}

In conducting the study, there a few limitations need to be acknowledged, although this study made several contributions to HRM research and the service industry. The first limitation of the study is related to the respondent's locations. Data in this study were collected from respondents working in international fast food restaurants in Amman, and may not be representative of the population, therefore limiting generalizability. Therefore, the result of this study should not be generalized and compared to other fast food restaurants in Jordan as different areas may influence the result of the study.

This study employed cross sectional research design with data collected for just once hence may not be able to provide clear understanding on the changes that took place over time. For example, the level of ITL might be change or be greater level after certain period of time.

Based on the limitations of the study, this study suggests few recommendations for future research. Among the others, the longitudinal research design is preferred to understand the changes that took place as employees start to experience the supportive HRMP and effects on various workplace outcomes such as ITL. Furthermore, it is recommended for future researchers to test a complex model with structural equation modeling especially when there is need to include mediating or moderating variable in the model. It is recommended for future studies to conduct probability sampling and conduct research involving different subjects, in different geographic locations and at different times to deal with external validity issues. 


\section{References}

Abeysekera, R. (2007). The impact of human resource management practices on marketing executive turnover of leasing companies in Sri Lanka. Contemporary Management Research, $3(3)$.

Abubakar, R., Chauhan, A., \& Kura, K. M. (2014). Relationship between perceived organizational politics, organizational trust, human resource management practices and turnover intention among Nigerian nurses. Human Resource Management Practices and Turnover Intention among Nigerian Nurses (May 14, 2014).

Al Momani, M. (2017, November 26). Improving Nurse Retention in Jordanian Public Hospitals. Retrieved September 24, 2019, from Medscape website: https://www.medscape.com/viewarticle/584052_2

Aladwan, K., Bhanugopan, R., \& Fish, A. (2014). Managing human resources in Jordanian organizations: challenges and prospects. International Journal of Islamic and Middle Eastern Finance and Management, 7(1), 126-138. https://doi.org/10.1108/imefm-09-2013-0104

Alfes, K., Shantz, A. D., Truss, C., \& Soane, E. C. (2013). The link between perceived human resource management practices, engagement and employee behaviour: A moderated mediation model. International Journal of Human Resource Management, 24(2), 330-351. https://doi.org/10.1080/09585192.2012.679950

Allen, D. G., Hancock, J. I., \& Vardaman, J. M. (2014). Analytical mindsets in turnover research. Journal of Organizational Behavior, 35(S1), S61-S86.

Allen, T. (2017). Effects of human resource factors on employee retention in the quick service industry. 1-51. Retrieved from https://digitalcommons.northgeorgia.edu/honors_theses

Almalki, M. J., FitzGerald, G., \& Clark, M. (2012). The relationship between quality of work life and turnover intention of primary health care nurses in Saudi Arabia. BMC health services research, 12(1), 314.

Awang, Z. (2012). Research methodology and data analysis. Shah Alam: Penerbit Universiti Teknologi MARA Press.

Awang, Z. (2015). SEM made simple: A gentle approach to learning structural equation modeling. Selangor: MPWS Rich Resources.

Baru, P. A., Ali, S., Amin, S. M., \& Hamid, R. A. (2016). A Review on Relationship between Reward and Turnover Intention. Journal of Advanced Review on Scientific Research ISSN, 19(online1), 2289-7887. Retrieved from http://www.akademiabaru.com/doc/ARSRV19_N1_P1_16.pdf

Blomme, R. J., Van Rheede, A., \& Tromp, D. M. (2010). The use of the psychological contract to explain turnover intentions in the hospitality industry: a research study on the impact of gender on the turnover intentions of highly educated employees. The International Journal of Human Resource Management, 21(1), 144-162. 
Bowling, N. A., \& Hammond, G. D. (2008). A meta-analytic examination of the construct validity of the Michigan Organizational Assessment Questionnaire Job Satisfaction Subscale. Journal of Vocational Behavior, 73(1), 63-77.

Cesário, F., \& Magalhães, S. (2017). Human resources management, citizenship behavior, and turnover intention in the Portuguese public administration. International Journal of Public Administration, 40(11), 979-988.

Chang, P. L., Chou, Y. C., \& Cheng, F. C. (2007). Career needs, career development programmes, organizational commitment and turnover intention of nurses in Taiwan. Journal of Nursing Management, 15(8), 801-810.

Chen, M. F., \& Tung, P. J. (2014). Developing an extended theory of planned behavior model to predict consumers' intention to visit green hotels. International journal of hospitality management, 36, 221-230.

Choi, J., Boyle, D. K., \& Dunton, N. (2014). A standardized measure: NDNQI nursing care hours indicator. Western Journal of Nursing Research, 36(1), 105-116

Davis, O. (2018). Strategies for Low Employee Turnover in the Hotel Industry labourshortagehosp... Solution: Minimum-M... Solution: Rewards, i... Solution: WBL. Retrieved from https://scholarworks.waldenu.edu/dissertations/5069/

Deery, M., (2008) Talent Management, Work-Life Balance and Retention Strategies. International Journal of Contemporary Hospitality Management, 20, 792-806. http://dx.doi.org/10.1108/09596110810897619

Derindag, O. F., \& Canakci, M. (2019). Strategic Human Resources Management in Innovative Firms. Anadolu Akademi Sosyal Bilimler Dergisi, 1(1), 52-77. Retrieved from https://dergipark.org.tr/anadoluakademi/issue/42510/508395

Derycke, H., Vlerick, P., Burnay, N., Decleire, C., D'Hoore, W., Hasselhorn, H. M., \& Braeckman, L. (2010). Impact of the effort-reward imbalance model on intent to leave among Belgian health care workers: A prospective study. Journal of Occupational and Organizational Psychology, 83(4), 879-893.

Edgar, F., \& Geare, A. (2005). HRM practice and employee attitudes: different measures-different results. Personnel review, 34(5), 534-549.

Ferreira, A. I., Martinez, L. F., Lamelas, J. P., \& Rodrigues, R. I. (2017). Mediation of job embeddedness and satisfaction in the relationship between task characteristics and turnover: A multilevel study in Portuguese hotels. International Journal of Contemporary Hospitality Management, 29, 248-267. doi: 10.1108/IJCHM-03-2015-0126

Feuerhahn, N., Kühnel, J., \& Kudielka, B. M. (2012). Interaction effects of effort-reward imbalance and overcommitment on emotional exhaustion and job performance. International Journal of Stress Management, 19(2), 105.

Food \& Beverage Magazine. (2019, March 4). Global Fast Food Market set for Explosive 
Growth, to Reach USD 645 billion by 2020 - Food \& Beverage Magazine. Retrieved September 22, 2019, from Food \& Beverage Magazine website: https://www.fb101.com/2019/03/global-fast-food-market-set-for-explosive-growth-to-reach-u sd-645-billion-by-2020/

Haider, S., Ahmed, M., \& Ali Asadullah, M. (2019). Effect of Relational Coordination on Employee Turnover Intentions through Job Satisfaction: The use of Structural Equation Modeling and Monte Carlo Simulation. ESIC MARKET Economic and Business Journal, 50(1), 19-42. https://doi.org/10.7200/esicm.162.0501.1i

Hair, J. F., Black, W. C., Babin, B. J., \& Anderson, R. E. (2010). Multivariate data analysis (7th ed.). Upper Saddle River, NJ: Pearson Prentice Education

Halawi, A. H. (2014). Stimuli and effect of the intention to leave the organization. European Scientific Journal, ESJ, 10(10), 184-197.

Hashim, S., Ghazali, H., Mohamad, S. F., Rasdi, R. M., \& Othman, M. (2019). The Effect of Distress and Social Support on Workplace Incivility and Turnover Intention among Malaysian Casual Dining Restaurant Employees: A Proposed Framework. International Journal of Academic Research in Business and Social Sciences, 9(6), 774-783. https://doi.org/10.6007/IJARBSS/v9-i6/6071

Holbrook Jr, R. L., \& Chappell, D. (2019). Sweet Rewards: An Exercise to Demonstrate Process Theories of Motivation. Management Teaching Review, 4(1), 49-62.

Holston Okae, B. (2018). The Effect of Employee Turnover in the Hospitality Industry: Quantitative Correlational Study. International Journal of Learning and Development, 8(1), 156. https://doi.org/10.5296/ijld.v8i1.12513

Holtom, B. C., Mitchell, T. R., Lee, T. W., \& Eberly, M. B. (2008). 5 Turnover and Retention Research: A Glance at the Past, a Closer Review of the Present, and a Venture into the Future. Academy of Management annals, 2(1), 231-274.

Hur, A., \& Achen, C. H. (2013). Coding voter turnout responses in the Current Population Survey. Public Opinion Quarterly, 77(4), 985-993.

Ikechukwu, O. C. (2017). The relationship between human resource management practices and intention to leave: The mediating role of job satisfaction. Unpublished thesis. Sintok, Universiti Utara Malaysia

Ikhlas, A., \& Al-kilani, M. H. (2010). Human resource management and diversity. The Dynamics of Managing Diversity: A Critical Approach: Third Edition, (January), 225-247. https://doi.org/10.4324/9780080966175

Iqbal, S., Ehsan, S., Rizwan, M., \& Noreen, M. (2014). The impact of organizational commitment, job satisfaction, job stress and leadership support on turnover intention in educational institutes. International Journal of Human Resource Studies, 4(2), 181.

Jaffari, A. R., Aziz, J., Hussain, Z., \& Akhtar, N. (2011). Prime and sub-prime factors of 
employee voluntary turnover in boom phase of industry: Empirical evidence from banking sector of Pakistan. African Journal of Business Management, 5(15), 6408-6414. https://doi.org/10.5897/AJBM10.1556

Jansen, P. G., \& Roodt, G. (2014). Conceptualising and measuring work identity. New York: Springer.

Jekanowski, M., Binkley, J. K., \& Eales, J. (2001). Convenience, accessibility, and the demand for fast food. Journal of Agricultural and Resource Economics, 26(1), 58-74.

Jeswani, S., \& Jaiswal, S. (2014). Impact of Organizational Commitment on Turnover Intention: An Empirical Study on Faculty Members of Technical Education Institutes of India. Asian Journal of Management, 5(2), 211-217.

Jha, S. (2009). Determinants of employee turnover intentions: A review. Management Today, $9(2)$.

Jordanlens. (2016). Restaurants Upgrade | USAID LENS. Retrieved September 22, 2019, from Jordanlens.org website: https://jordanlens.org/activity/restaurants-upgrade

Karavardar, G. (2013). Determining the mediating effect of job satisfaction on turnover intention: A study in the hazelnut industry of Giresun. Journal of Academic Research in Economics (JARE), (3), 376-396.

Khawaldeh, K., Muala, A. M. Al, \& Ziadat, M. T. AL. (2014). Antecedents and Mediator of Turnover Intention amongst Employees in Private Communications Sector in Jordan: A Structural Equation Modeling (SEM) Approach. Journal of Management and Sustainability, 4(3), 135-144. https://doi.org/10.5539/jms.v4n3p135

Kinicki, A. J., Carson, K. P., \& Bohlander, G. W. (1992). Relationship between an organization's actual human resource efforts and employee attitudes. Group \& Organization Management, 17(2), 135-152.

Kumar, R., Ramendran, C., \& Yacob, P. (2012). A Study on Turnover Intention in Fast Food Industry: Employees' Fit to the Organizational Culture and the Important of their Commitment. International Journal of Academic Research in Business and Social Sciences, 2(5), 2222-6990.

Long, C. S., \& Perumal, P. (2014). Examining the impact of human resource management practices on employees' turnover intention. International Journal of Business and Society, 15(1), 111-126.

Maltarich, M. A., Reilly, G., \& DeRose, C. (2019). A theoretical assessment of dismissal rates and unit performance, with empirical evidence. Journal of Applied Psychology. Advance online publication. http://dx.doi.org/10.1037/apl0000448

March, J. G., \& Simon, H. A. (1958). Organizations. New York: John Wiley.

Mburu, M. W. (2018). Factors Influencing Employee Turnover in the Hospitality Industry in Kenya: A Case Study of Hill Park Hotel (Doctoral dissertation, United States International 
University-Africa).

Memon, M. A., Salleh, R., Harun, H., Rashid, R. A., \& Bakar, Z. A. (2014). Training, engagement, social exchange ideology and employee turnover: A proposed moderated mediation conceptual framework. Australian Journal of Basic \& Applied Sciences, 8(5), 151-156.

Meyer, J. P., \& Smith, C. A. (2000). HRM practices and organizational commitment: Test of a mediation model. Canadian Journal of Administrative Sciences/Revue canadienne des sciences de l'administration, 17(4), 319-331.

Mvula, R. T. (2018). Empirical study of the reverse-causality between organisational performance and employee behaviour in the agricultural manufacturing sector of Malawi. University of the Witwatersrand., 10(2), 1-15.

Obeidat, O. (2014, September 11). Restaurants of all types and shapes 'good business', thanks to change in lifestyles, refugee influx. Retrieved September 22, 2019, from Jordan Times website: http://www.jordantimes.com/news/local/restaurants-all-types-and-shapes-good-business\%E2 $\% 80 \% 99$-thanks-change-lifestyles-refugee-influx

Omar, S., \& Noordin, F. (2013). Career Adaptability and Intention to Leave among ICT Professionals: An Exploratory Study. Turkish Online Journal of Educational Technology-TOJET, 12(4), 11-18.

Omar, S., \& Noordin, F. (2015). Work Happiness and Intention to Leave of ICT Professionals in Malaysia: An Exploratory Study. In Proceedings of the Colloquiumon Administrative Science and Technology (pp. 69-77). Springer Singapore.

Omar, S., \& Noordin, F. (2016). Career Commitment and Intention to Leave Among ICT Professionals in Malaysia. In Proceedings of the 1st AAGBS International Conference on Business Management 2014 (AiCoBM 2014) (pp. 309-318). Springer Singapore.

Pei, C. L., \& Chee, L. W. (2019). The impacts of work-life balance and self-efficacy on job satisfaction among fast food industry workers in Ipoh, Perak. Unpublished thesis. Universiti Tunku Abdul Rahman. Negeri Perak, Malaysia

Phillips, J. (1996). Accountability in human resource management. Houston, USA: Gulf Publishing

Tews, M. J., Michel, J. W., \& Ellingson, J. E. (2013). The Impact of Coworker Support on Employee Turnover in the Hospitality Industry. Group and Organization Management, 38(5), 630-653. https://doi.org/10.1177/1059601113503039

Türkmen, E., \& Taşpınar, O. (2019). The Effects of Job Satisfaction of Employees in Fast-Food Businesses on the Intention to Leave Job: The Case of Kurklareli. Journal of Tourism and Gastronomy Studies, 7(2), 885-897. https://doi.org/10.21325/jotags.2019.397

Prouska, R., Prouska, R., Psychogios, A. G., Psychogios, A. G., Rexhepi, Y., \& Rexhepi, Y. 
(2016). Rewarding employees in turbulent economies for improved organisational performance: Exploring SMEs in the South-Eastern European region. Personnel Review, 45(6), 1259-1280.

Reid, C. (2007). Encyclopedia of Business and Finance (2nd edition). Reference Reviews, 21(5), p28. https://doi.org/10.1108/09504120710755518

Saraih, U., Aris, Z., Zuraini, A., Sakdan, M. F., \& Ahmad, R. (2016). Factors affecting turnover intention among academician in the Malaysian Higher Educational Institution. Review of Integrative Business and Economics Research, 6(1), 1-15.

Sawaneh, I. A., \& Kamara, F. K. (2019). An Effective Employee Retention Policies as a Way to Boost Organizational Performance. Journal of Human Resource Management, 7(2), 41-48.

Self, T. T., \& Gordon, S. (2019). The impact of coworker support and organizational embeddedness on turnover intention among restaurant employees. Journal of Human Resources in Hospitality \& Tourism, 18(3), 394-423. https://doi.org/10.1080/15332845.2019.1599789

Soane, E. (2013). Leadership and employee engagement. Employee Engagement in Theory and Practice, Routledge, London, 149-162.

Stewart, G. L., \& Brown, K. G. (2019). Human resource management. Wiley.

Straits Research. (2019). Fast Food Market: Information by Type (Burgers, Pizzas, Chinese Food), Distribution Platform (Quick Service Restaurants, Food Delivery Services) and Regional Outlook-Forecast Till 2026. Retrieved September 22, 2019, from Straitsresearch.com website: https://straitsresearch.com/report/fast-food-market

Sun, Z. F., Wei, J., \& Lu, H. Z. (2010, December). Turnover of airlines employees: Examining empirically the influence of work life-benefits. In Information Science and Engineering (ICISE), 2010 2nd International Conference on (pp. 834-837). IEEE.

Tuji, A. (2013). An Assessment of the Causes of Employee Turnover in Oromia Public Service Organizations (Doctoral dissertation, Thesis. 90).

Wayne, S. J., Shore, L. M., \& Liden, R. C. (1997). Perceived organizational support and leader-member exchange: A social exchange perspective. Academy of Management Journal, 40(1), 82-111. https://doi.org/10.2307/257021

Xiao, A., Yang, S., \& Iqbal, Q. (2018). Factors Affecting Purchase Intentions in Generation Y: An Empirical Evidence from Fast Food Industry in Malaysia. Administrative Sciences, 9(1), 4. https://doi.org/10.3390/admsci9010004

Yamona T, M. (2014). A study on employee's turnover intention in banking industry (Doctoral dissertation, Universiti Utara Malaysia).

Yumusak, \& Yildiz, H. (2011). Mediating Role of Affective Commitment in HRM Practices and Turnover Intention Relationship: A Study in a Developing Context. Business and Economics Research Journal, 2(4), 135-158. 


\section{Macrothink}

International Journal of Human Resource Studies

ISSN 2162-3058 2019, Vol. 9, No. 4

Zimmerman, R. D., \& Darnold, T. C. (2009). The impact of job performance on employee turnover intentions and the voluntary turnover process: A meta-analysis and path model. Personnel review, 38(2), 142-158.

Zion Market Research. (2019, July 12). Global Industry Trends in Fast Food Market Size \& Share Will Surpass USD 690.80 Billion by 2022. Retrieved from GlobeNewswire News Room website: https://www.globenewswire.com/news-release/2019/07/12/1882007/0/en/Global-Industry-Tre nds-in-Fast-Food-Market-Size-Share-Will-Surpass-USD-690-80-Billion-by-2022.html

\section{Copyright Disclaimer}

Copyright for this article is retained by the author(s), with first publication rights granted to the journal.

This is an open-access article distributed under the terms and conditions of the Creative Commons Attribution license (http://creativecommons.org/licenses/by/4.0/). 